\title{
IMPACTS ON AIR QUALITY INDEX IN THE INDUSTRIAL TOWN OF ASANSOL (WEST BENGAL, INDIA) DUE TO COVID-19 LOCKDOWN
}

\author{
Rajrupa Ghosh \\ Post Graduate Department of Zoology, Banwarilal Bhalotia College, Ushagram, \\ Asansol-713303, West Bengal (India) \\ Email- rajrupaphd@gmail.com
}

\begin{abstract}
:
The lockdown phase associated with COVID-19 pandemic initiated in full swing on and from 25th March, 2020 as preventive measures against the spreading of Corona virus. The objective of this study is to analyse the status of air quality of before and after lockdown in Asansol city which is second largest city of West Bengal, India and also known as "coal mining city". Secondary data of five parameters like $\mathrm{CO}, \mathrm{SO}_{2}, \mathrm{NO}_{2}, \mathrm{PM} 2.5$ and PM10 have been collected from Central Pollution Control Board, India. The result shows significant decrease of five parameters from $42.4 \%(\mathrm{CO})$ to $63.4 \%\left(\mathrm{NO}_{2}\right)$ due to close down of all industrial and transport activities during lockdown period. Based on different investigation a green belt development plan for this polluted city has been suggested for sustainable air quality management.
\end{abstract}

Keywords: COVID-19, lockdown, Air quality index, Asansol.

\section{INTRODUCTION:}

Coronavirus disease 2019 (COVID-19) is an infectious disease caused by severe acute respiratory syndrome coronavirus 2 (SARSCoV-2), which has been identified by a group of virologists $^{1}$ and published in Nature, 1968. Corona viruses are zoonotic, meaning that the viruses are transmitted between animals and humans. It was first identified in December 2019 in Wuhan, China and has resulted in an ongoing pandemic ${ }^{2-6}$. The first confirmed case has been traced back to 17 November, 2019 and 20 January, 2020 WHO issued a statement saying that there was evidence of human-tohuman transmission. As of 17 August, 2020, more than 26 lakhs cases have been reported across India, resulting in more than 52,000 deaths. Among the highly COVID-19 affected states in India, West Bengal stands at a vulnerable situation with $1,18,000$ confirmed cases till August 15, 2020. Common symptoms include fever, cough, fatigue, shortness of breath, and loss of smell and taste. While the majority of cases result in mild symptoms, some progress to acute respiratory distress syndrome (ARDS) possibly precipitated by cytokine storm, multi-organ failure, septic shock, and blood clots. The time from exposure to onset of symptoms is typically around five days, but may range from two to fourteen days.

The first confirmed case of COVID-19 in India was reported on 30 January, 2020 in the southern state of Kerala7. Till now in India the most affected cities are Mumbai, Delhi, Chennai, Ahmedabad, Pune, Indore, Kolkata, Jaipur, Jodhpur etc. Finally, the CDC (Centres for Disease Control) declared that the virus can transmit person to person through respiratory 
droplets and thus an infected person can spread the virus to the healthy persons around them. This is spread through shaking of hands or any kinds of close personal contact (touching of eyes, nose, mouth). Infants, older people and those with medical problems like high blood pressure, cancer, diabetes, heart problem, asthma are more prone to develop this disease ${ }^{8-}$ 10,5 .

Social lockdown is considered the most effective measure to control COVID-1911,12. On 19th of March, honourable Prime Minister Narendra Modi first declared for a lockdown of 21 days which was started through a 'JANATA CURFEW' on 22 $2^{\text {nd }}$ March and from 25th March, 2020 lockdown started. There was a Lakhsman Rekha on our door step. All Indian cities were locked down and the majority of industrial and commercial activities have been forced to stop their activities until further notice. Citizens are requested to stay at home and don't leave it except for very specific reasons (buy essential supplies, medical appointments...). In add to these safety actions, the authorities decided also to shut down transportation and travel in and out of the country, close down schools, universities, restaurants and mosques, and to ban the mass gatherings across India. To prevent rapid transmission of coronavirus, countrywide lockdown had been enforced through the halting of economic production and restrictions on mobility of the citizens ${ }^{7}$. Lockdown extended in India upto $31^{\text {st }}$ May, 2020 and from $1^{\text {st }}$ June, 2020 UNLOCK 1 started with lots of do's and don'ts.

Several studies reported that reducing anthropogenic activities during COVID-19 outbreak plays a significant role in air pollution formation and could influence the total ambient air quality ${ }^{13,14}$. $\mathrm{PM} 10, \mathrm{NO}_{2}$ and $\mathrm{SO}_{2}$ are very common ambient air pollutants in urban environments and caused severe health-related problems like respiratory and cardiovascular disorders, blood pressure and lung cancer ${ }^{15,16}$. These pollutants arise from anthropogenic sources, including road traffic and industrial activities ${ }^{17,18}$.

In this context, the objective of the present paper is to assess the atmospheric $\mathrm{CO}, \mathrm{SO}_{2}$, $\mathrm{NO}_{2}$, PM2.5 and PM10 concentrations of industrial town, Asansol, before and after lockdown measures against the propagation of COVID-19 pandemic.

\section{MATERIALS AND METHODS:}

\subsection{Study site}

In West Bengal, Asansol (23.673N, 86.952 $\mathrm{E}$ ) which is situated in the Western part of Burdwan district of West Bengal in the eastern India (Fig. 1), is the second largest city of the state. It is also known as 'coal mining city' because, the entire region of Asansol sits on layers and layers of coal. The coal is of highquality superior coal.

Over the last ten years there was hectic develo pment in the area in terms of industrieslike Indian Iron and Steel Company (IISCO), Burnpur Cement Limited (BCL), Dishergarh Power Supply Company limited, Joy Balaji Sponge Iron Private Limited, Shyam Gel Limited (Power Divisions) etc. In Asansol the ambient air quality has rapidly deteriorated ${ }^{19-21}$ due to mainly for industrialization, modernization and urbanization, which is affecting human population, other animals and plant communities.

\subsection{Data sources and analysis}

In this study, five parameters like $\mathrm{CO}, \mathrm{SO}_{2}$, $\mathrm{NO}_{2}, \mathrm{PM} 2.5$ and PM10 have been considered to 
evaluate the deviation of air quality before and after lockdown period (January 1, 2020 to July $31,2020)$. The secondary data of abovementioned selected pollution parameters has been obtained from the Central Pollution Control Board (CPCB), Govt. of India. The maps regarding variation of $\mathrm{NO}_{2}$ and aerosol concentration over India have been obtained from European space agency (ESA) and the National aeronautics and Space Administration (NASA) individually $22-23$. The five parameters (CO, $\mathrm{SO}_{2}, \mathrm{NO}_{2}, \mathrm{PM} 2.5$ and PM10) measured from January 1, 2020 to July 31, 2020 were subject to ANOVA using SYSTAT.

\section{RESULTS:}

Lockdown has transferred the air quality significantly which is reflected in the Table 1 and Fig. 2, 3, in which $\mathrm{CO}$ level decreased from 0.82 to $0.47 \mathrm{mg} / \mathrm{m}^{3}, \mathrm{SO}_{2}$ decreased from 17.4 $\mu \mathrm{g} / \mathrm{m}^{3}$ to $9.32 \mu \mathrm{g} / \mathrm{m}^{3}, \mathrm{NO}_{2}$ decreased from $35.70 \mu \mathrm{g} / \mathrm{m}^{3}$ to $13.06 \mu \mathrm{g} / \mathrm{m}^{3}$, PM2.5 decreased from $79.98 \mu \mathrm{g} / \mathrm{m}^{3}$ to $30.62 \mu \mathrm{g} / \mathrm{m}^{3}$ and PM10 decreased from $148.82 \mu \mathrm{g} / \mathrm{m}^{3}$ to $68.67 \mu \mathrm{g} / \mathrm{m}^{3}$. Even after UNLOCK 1 the air quality parameters showing satisfactory result than pre lockdown period. The decreased percentage of five parameters are shown in Fig. 4. ANOVA data (Table 2) also highlights significant variations in surface atmospheric $\mathrm{CO}, \mathrm{SO}_{2}$, $\mathrm{NO}_{2}$, PM2.5 and PM10 between months.

\section{DISCUSSION:}

Rapid industrialization and urbanization lead to a great role in air pollution in Asansol City. For rapid spreading the contagious virus COVID-19, these factories, transports and other anthropogenic activities were completely shut down on and from 25th March,2020, that resulted in the reduction of $\mathrm{CO}, \mathrm{SO}_{2}, \mathrm{NO}_{2}$, PM2.5 and PM10 emission.
Air quality index (AQI) is the assessment of air quality and lower AQI means good air quality. The emission of $\mathrm{CO}, \mathrm{SO}_{2}, \mathrm{NO}_{2}, \mathrm{O}_{3}$ concentration are greatest environmental problem for developed countries ${ }^{24} . \mathrm{NO}_{2}$ is emitted from high temperature combustion process of fossil fuels, especially diesel, thermal power generation, industrial emissions, auto mobile exhaust and shipping25-28 and it causes many health hazards, acid rain, nitrate aerosols 29 . According to report by European Space Agency (ESA) and National Aeronautics and Space Administration (NASA) suggests that environmental quality improved the emission of $\mathrm{NO}_{2}$ reduced upto 30\% (Fig. 5,6). NASA collects data using OMI (Ozone Monitoring Institute) on its AURA satellite. While ESA collects data through Sentinel $-5 \mathrm{P}$ Satellite using TROPOMI (Tropospheric Monitoring Instrument and Ozone Monitoring Instrument). $\mathrm{CO}$ and $\mathrm{SO}_{2}$ are an important indicators of air pollutants that are related to coal consumption, petroleum and chemical fuel emissions. PM2.5 and PM10 derived from road traffic, industrial exhaust emission, construction works and road dust.

Li et al. 30 stated that at Yangtze River delta region in China, the emission of $\mathrm{NO}_{2}, \mathrm{SO}_{2}$ and PM2.5 decreased in the air than the previous years. Similar result has been found in Almaty, Kazakastan by Kerimrayet al. ${ }^{31}$ where $\mathrm{CO}, \mathrm{NO}_{2}$ and PM2.5 level reduced by $49 \%, 35 \%$ and $21 \%$ accordingly than pre-lockdown period. In European countries like France, Spain, Italy and Germany showed improved air quality during lockdown due to controlled vehicle movements, limited usage fuel energy and partially closed industrial sectors etc. ${ }^{32,33}$. Even in Wuhan City, China 30\% reduction of $\mathrm{NO}_{2}$ was also found in 2020 than 201918. In Salé City, Morocco, the concentration of PM10, $\mathrm{NO}_{2}$ and $\mathrm{SO}_{2}$ were decreased respectively, by $75 \%$, 
96\% and 49\% within few days after implementation of COVID-19 lockdown ${ }^{34}$.

Like European countries and other Asian countries, India is also blessed with good air quality after 24th March, 202035-40. Sharma et al.,24also noticed remarkable positive modifications of air quality $\left(\mathrm{CO}_{2}, \mathrm{SO}_{2}, \mathrm{NO}_{2}, \mathrm{O}_{3}\right.$, PM2.5 and PM10) during March and April, 2020 across the 22 cities in India than the same time period in 2017. Same result has been found by Beraet al. ${ }^{41}$ in Kolkata, West Bengal, where the pollutants like $\mathrm{CO}, \mathrm{SO}_{2}, \mathrm{NO}_{2}, \mathrm{PM} 2.5$ and PM10 are significantly decreased during lockdown compared with previous three years because of complete stop of vehicle movement, burning of biomass and dust particles from construction works.

The long-term lockdown system diminishes the materialistic consumption and energy usage as per Jribiet al.42. Eroglu43 noticed prominent decline in utilization of coal consumption during the first half of 2020 in comparison with the past years. Presently, as the country is passing through lockdown phase, the industrial and transport activities are paused, reduces the concentration of $\mathrm{CO}, \mathrm{SO}_{2}, \mathrm{NO}_{2}, \mathrm{PM} 2.5$ and PM10 in the atmosphere of industrial and most polluted city like Asansol, which is also a part of Raniganj Coalfield area.

From the environmental point of view lockdown is very much effective for air quality, but, in case of economic point of view of a country, it is not suggestable. So, for sustainable management of air quality, plants help us a lot, because they are the principal recipient of different types of air pollutants and act as a sink $^{44}$. Salih et al., 2017 identified some plant species (Ficus bengalensis -Banyan, Psidium guajava - Guava, Mangifera indica Mango,Hibiscus rosa-sinensis - China rose,
Bougainvillea spectabilis - Bougainvillea, Neolamarkiacadamba - Kadam/ Burfower tree, Ficus religiosa - Peepul,Cascabelathevetia Yellow oleander, Cassia siamea - Cassod tree, Ricinus communis - Castor oil plant, Eucalyptus globus - Southern blue gum, Azadirachta indica - Neem) which has high absorption capacity of specific pollutants. The improvement of green envelop by plantation of tolerant species can combat air pollution of this particular industrial zone. The selection of plant species (based on tolerance level) is a principal factor for the mitigation of urban air pollution. Choudhury and Banerjee 45 indicated as per APTI (Air Pollution Tolerant Index) values of some plants like Mangifera indica (Mango), Azadirachtaindica (Neem), Ficus benghalensis (Banyan), Psidium guayava (Guava), Eucalyptus (Eucalyptus), Alstoniascholaris (Chattiyan), Butea monosperma (Palash), Moringa oleifera (Sajina), Dalbergia sisoo (Sissoo), Artocarpus heterophylus (Jackfruit), Hibiscus rosasinensis (Jaba), Calotropis gigantia (Akanda), Ricinus communis (Bheranda), Murrayapaniculata (Kamini), Citrus aurantium (Nebu), Aegle marmelos (Beal), Ixora coccinea (Rangan), Nerium indicum (Karabi), Tamarindus indicus (Tentul), Thevetia peruviana (Korubi) and Tabernaemontanadivaricata (Tagar) are tolerant species in Asansol and can be used as greenbelt development in this area.

\section{CONCLUSION:}

This study investigates for better insight of COVID-19 and how current lockdown effects the various parameter like $\mathrm{CO}, \mathrm{SO}_{2}, \mathrm{NO}_{2}, \mathrm{PM} 2.5$ and PM10 which is responsible for air pollution. The improvement of air quality opened our eye to the magnitude of damage caused by unregulated anthropogenic activities in the city. There is a chance that when the lockdown period is over environmental pollution can be 
back with more pace so human effort towards saving the environment can do everlasting effect. Strict implementation of environmental related laws along with mass awareness should be followed to eco- restore the city atmosphere.

\section{ACKNOWLEDGEMENT:}

The authors are grateful to the Central Pollution Control Board (CPCB), Govt. of India, for providing necessary data related with air quality changes in Asansol of before and after of the lockdown period. The authors would also like to acknowledge the European Space agency (ESA), USA and National Aeronautics and Space Administration (NASA).

\section{REFERENCES:}

Tyrrell, D.A.J., Almeida, J.D., Berry, D.M., Cunningham, C.H., Hamre, D., Hofstad, M.S., Mallucci, L. and McIntosh, K., 1968. Coronaviruses. Nature 220: 650.

Huang, C., Wang, Y., Li, X., Ren, L., Zhao, J., $\mathrm{Hu}$, Y., et al., 2020. Clinical features of patients infected with 2019 novel coronavirus in Wuhan, China. Lancet 395: 497-506. https://doi.org/10.1016/ S01406736(20)30183-5.

Huang, X., Ding, A., Gao, J., Zheng, B., Zhou, D., Qi, X., et al., 2020. Enhanced secondary pollution offset reduction of primary emissions during COVID-19 lockdown in China. Earth Ar Xiv. https:// doi.org/10.31223/osf.io/hvuzy.

Zhou, P., Yang, X.-L., Wang, X.-G., Hu, B., Zhang, L., Zhang, W., et al., 2020. Discovery of a novel coronavirus associated with the recent pneumonia outbreak in humans and its potential bat origin. Bio Rxiv. https://doi.org/10.1101/2020.01.22.9149 $\underline{52}$.

Zhou, F., Yu, T., Du, R., et al., 2020. Clinical course and risk factors for mortality of adult inpatients with COVID-19 in Wuhan, China: a retrospective cohort study. Lancet S01406736(20): 30566-30573.

https://doi.org/10.1016/s01406736(20)30566-3.

Zhu, N., Zhang, D., Wang, W., Li, X., Yang, B., Song, J., et al., 2020. A novel coronavirus from patients with pneumonia in China, 2019. N. Engl. J. Med. 382: 727-733. https://doi. org/10.1056/NEJMoa2001017.

Gautam, S. and Hens, L. (2020). SARS-CoV-2 pandemic in India: what might we expect? Environ. Dev. Sustain. 22: 3867-3869. https://doi.org/10.1007/s10668-02000739-5

Arabi, Y.M., Deeb, A.M., Al-Hameed, F., Mandourah, Y., Almekhlafi, G.A., Sindi, A.A., AlOmari, A., Shalhoub, S., Mady, A., Alraddadi, B., Amotairi, A.A., Khatib, K., Abdulmomen, A., Qushmag, I., Solaiman, O., Al-Aithan, A.M., Al-Raddadi, R., Ragab. A., A.A., Kharaba, A., Jose, J., Dabbagh, T., Fowler, R.A., Balkhy, H.H., Merson, I. and Hayden, F.G., 2019. Saudi critical care trials group. Macrolides in critically ill patients with Middle East Respiratory Syndrome. Int. J. Infect. Dis. 81: 184-190.

Ashour, H.M., Elkhatib, W.F., Rahman, M.M. and Elshabrawy, H.A., 2020. Insight into the recent 2019 novel coronavirus (SAR-CoV-2) in light of past human coronavirus outbreaks. Pathogens 9 (3): E186.

Dong, L., Hu, S. and Gao, J., 2020. Discovering drugs to treat coronavirus disease 2019 (COVID19). Drug. Discov. Ther. 14 (1): 5860.

Das, K. and Patial, B., 2020. The synergy between philosophy and science, need of the contemporary society. Int. J. Humanities Soc. Sci. Res. 6 (1): 45-51. 
Paital, B., Das, K. and Parida, S.K., 2020. Inter nation social lockdown versus medical care against COVID-19, a mild environmental insight with special reference to India. Sci. Total Environ. 728: 138914.

He, G., Pan, Y. and Tanaka, T., 2020a. COVID19, City Lockdown, and Air Pollution: Evidence from China. MedRxiv, 2020.03.29.20046649.

https://doi.org/10.1101/

2020.03.29.20046649

Isaifan, R.J., 2020. The dramatic impact of coronavirus outbreak on air quality: has it saved as much as it has killed so far? 6 (3): 275-288. https://doi.org/10.22034/ gjesm.2020.03.01.

Koken, P.J., Piver, W.T., Ye, F., Elixhauser, A., Olsen, L.M. and Portier, C.J., 2003. Temperature, air pollution and hospitalization for cardiovascular diseases among elderly people in Denver. Environ. Health Perspect. 111 (10): 1312-1317.

Le Tertre, A., Medina, S., Samoli, E., Forsberg, B., Michelozzi, P., Boumghar, A., Vonk, J.M., Bellini, A., Atkinson, R., Ayres, J.G., Sunyer, J., Schwartz, J. and Katsouyanni, K., 2002. Short-term effects of particulate air pollution on cardiovascular diseases in eight European cities. J. Epidemiol. Community Health. 56: 773-779.

Thorpe, A.J. and Harrison, R.M., 2008. Sources and properties of non-exhaust particulate matter from road traffic: a review. Sci. Total Environ. 400: 270-282.

He, L., Zhang, S., Hu, J., Li, Z., Zheng, X., Cao, Y., Xu, G., Yan, M. and Wu, Y., 2020b. Onroad emission measurements of reactive nitrogen compounds from heavy duty diesel trucks in China. Environ. Pollut. 262: $114280 . \quad$ https://doi.org/10.1016/j. envpol.2020.114280.
Banerjee, D. and Agarwalla N.L., 2006. Dispersion Modelling for a Chemical Manufacturing Plant, Indian J. Air Pollut. Control 6 (1): 29-39.

Banerjee, D. et al., 2005. Analysis of air quality in Asansol City, Environ. Pollut. Control J. 8 (6): 54-60

Dey M., 2013. A Contingent Valuation Approach to Estimate the Maximum Willingness-to-pay for Improved Air Quality in Asansol, Industrial Area of West Bengal. Int. J. Trend Econ. Manag. Tech. Vol. II, Issue IV.

ESA, 2020a. ESA, 2020. https://www.esa.int/Applications/Observi ng_the_Earth/Copernicus/Sentinel-5P/ Air pollution drops_ in_ India following lockdown.

NASA., 2020. NASA, 2020.

https://earthsky.org/earth/satelliteimages-air-pollution-india-covid19.

Sharma, P. and Dhar, A., 2018. Effect of hydrogen supplementation on engine performance and emissions. Int. J. Hydrog. Energy 43: 7570-7580.

Burnett, R.T., Stieb, D., Brook, J.R., Cakmak, S., Dales, R., Raizenne, M., Vincent, R. and Dann, T., 2004. Associations between shortterm changes in nitrogen dioxide and mortality in Canadian cities. Arch. Environ. Health. 59: 228-236.

Tobías, A., Carnerero, C., Reche, C., Massagué, J., Via, M., Minguillón, M.C., Alastuey, A. and Querol, X., 2020. Changes in air quality during the lockdown in Barcelona (Spain) one month into the SARS-CoV-2 epidemic. Sci. Total Environ. 726: 138540. https:// doi.org/10.1016/j.scitotenv.2020.138540.

He, M. Z., Kinney, P. L., Li, T., Chen, C., Sun, Q., Ban, J., et al., 2020c. Short- and intermediate-term exposure to $\mathrm{NO}_{2}$ and mortality: a multi-county analysis in China. 
Environ. Poll. 261: 114165. https://doi.org/10.1016/j.envpol.2020.114 165.

Sharma, S., Zhang, M., Gao, J., Zhang, H. and Kota, S. H., 2020. Effect of restricted emissions during COVID-19 on air quality in India. Sci. Total Environ. 728: 1-8. https://doi.

org/10.1016/j.scitotenv.2020.138878

Biswas, M.S., Ghude, S.D., Gurnale, D., Prabhakaran, T. and Mahajan, A.S. (2019). Simultaneous observations of nitrogen dioxide, formaldehyde and ozone in the Indo-Gangetic Plain. Aerosol Air Qual. Res. 19: 1749-1764.

Li, L., Li, Q., Huang, L., Wang, Q., Zhu, A., Xu, J., et al., 2020. Air quality changes during the COVID19 lockdown over the Yangtze River Delta Region: an insight into the impact of human activity pattern changes on air pollution variation. Sci. Total Environ. 732: 1-11. https://doi. org/10.1016/j.scitotenv.2020.139282.

Kerimray, A., Baimatova, N., Ibragimova, O. P., Bukenov, B., Kenessov, B., Plotitsyn, P., et al., 2020. Assessing air quality changes in large cities during COVID-19 lockdowns: the impacts of traffic free urban conditions in Almaty, Kazakhstan. Sci. Total Environ. 730: 1-8. https:// doi.org/10.1016/j.scitotenv.2020.139179

Muhmmad, S., Long, X. and Salman, M. 2020. COVID-19 pandemic and environmental pollution: a blessing in disguise? Sci. Total Environ. 728: $1-5$. https://doi.org/10.1016/j.scito tenv.2020.138820.

ESA, 2020b. 2020. https://www.esa.int/Applications/Observi ng_the_Earth/Copernicus/Sentinel-5P/ Coronavirus_lockdown_leading_to_drop_in_ pollution_across_Europe.
Otmani, A., Benchrif, A., Tahri, M., Bounakhla, M., Chakir, E.M., Bouch, M. El. and Krombi, M. 2020. Impact of Covid-19 lockdown on $\mathrm{PM} 10, \mathrm{SO}_{2}$ and $\mathrm{NO}_{2}$ concentrations in Salé City (Morocco). Sci. Total Environ., 73:139 541, 10.1016/j.scitotenv.2020.139541

Mahato, S., Pal, S., Ghosh and K.G., 2020. Effect of lockdown amid COVID-19 pandemic on air quality of the megacity Delhi, India. Sci. Total Environ. 730: 139086

Gautam, S. 2020a. COVID-19: air pollution remains low as people stay at home. Air. Qual. Atmos. Hlth. https://doi.org/10.1007/s11869-02000842-6.

CPCB, 2020. Impact of lockdown (25th March to 15th April) on air quality. Ministry of Environment, Forest and Climate Change, Govt. of India, Delhi, 1-62. https://cpcb.nic.in/latest-cpcb.php.

Mate, A., Killian, J. A., Wilder, B., Charpignon, M., Awasthi, A., Tambe, M., et al., 2020. Evaluating COVID-19 Lockdown Policies for India: a Preliminary Modeling Assessment for Individual States. SSRN, 3575207. https://doi.org/10.2139/ssrn.3575207.

Mitra, A., Chaudhuri, T.R., Mitra, A., Pramanick, P., Zaman, S., Mitra, A., Chaudhuri, T.R., Mitra, A., Pramanick, P. and Zaman, S., 2020. Impact of COVID-19 related shutdown on atmospheric carbon dioxide level in the city of Kolkata. Sci. Educ. 6 , 84-92. https://sites.google.com/site/pjsciencea.

Lau, H., Khosrawipour, V., Kocbach, P., Mikolajczyk, A., Schubert, J., Bania, J., et al., 2020. The positive impact of lockdown in Wuhan on containing the COVID-19 outbreak in China. J. Travel Med. 37: 1-14. https://doi.org/10.1093/jtm/taaa037 
I J R B A T, Issue (IX), Vol. II, May 2021: 257-268

A Double-Blind Peer Reviewed \& Refereed Journal
e-ISSN $2347-517 X$

Original Article
Bera, B., Bhattacharjee, S., Shit, P.K., Sengupta, N. and Saha, S., 2020. Significant impacts of COVID-19 lockdown on urban air pollution in Kolkata (India) and amelioration of environmental health. Environ. Dev. Sustain. https://doi.org/10.1007/s10668020-00898-5

Jribi, S., Ismai, H.B., Doggui, D. and Debbabi, K., 2020. COVID-19 virus outbreak lockdown: What impacts on household food wastage? Environ. Dev. Sustain. 22: 39393955. https://doi.org/10.1007/s10668020-00740-y

Eroglu, H., 2020. Effects of Covid-19 outbreak on environment and renewable energy sector. Environ. Dev. Sustain. https://doi.org/10.1007/s10668-02000837-4.

Kaur, M. and Nagpal, A. K., 2017. Evaluation of air pollution tolerance index and anticipated performance index of plants and their application in development of green space along the urban areas. Environ. Sci. Pollut. R. 24:

18881-18895.

https://doi.org/10.1007/s1135 6-0179500-9.

Choudhury, P. and Banerjee, D., 2009. Biomonitoring of Air Quality in the Industrial Town of Asansol using the Air Pollution Tolerance Index Approach. Res. J. Chem. Environ. Vol. 13: (1).

Table 1. Emission level of selective pollutants (monthly average) present in air before and after lockdown in Asansol City

\begin{tabular}{|l|c|c|c|c|c|}
\hline & $\begin{array}{c}\mathrm{CO} \\
\left(\mathrm{mg} / \mathrm{m}^{3}\right)\end{array}$ & $\begin{array}{c}\mathrm{SO}_{2} \\
\left(\mu \mathrm{g} / \mathrm{m}^{3}\right)\end{array}$ & $\begin{array}{c}\mathrm{NO}_{2} \\
\left(\mu \mathrm{g} / \mathrm{m}^{3}\right)\end{array}$ & $\begin{array}{c}\mathrm{PM} 2.5 \\
\left(\mu \mathrm{g} / \mathrm{m}^{3}\right)\end{array}$ & $\begin{array}{c}\mathrm{PM} 10 \\
\left(\mu \mathrm{g} / \mathrm{m}^{3}\right)\end{array}$ \\
\hline $\begin{array}{l}\text { Before lockdown } \\
\text { (Jan 1 - March 24) }\end{array}$ & 0.829167 & 17.4731 & 35.69976 & 79.97786 & 148.8502 \\
\hline $\begin{array}{l}\text { After lockdown } \\
\text { (March 25 - May 31) }\end{array}$ & 0.473529 & 9.328209 & 13.06075 & 30.61821 & 68.67657 \\
\hline $\begin{array}{l}\text { Unlock Period } \\
\text { (June 1 - July 21) }\end{array}$ & 0.444918 & 3.089508 & 7.593443 & 25.77246 & 49.54787 \\
\hline
\end{tabular}

Table 2. ANOVA for the atmospheric $\mathrm{CO}, \mathrm{SO}_{2}, \mathrm{NO}_{2}, \mathrm{PM} 2.5$ and $\mathrm{PM1O}$ between months

\begin{tabular}{|c|c|c|}
\hline Parameters & F-obs & F-crit \\
\hline $\mathrm{CO}$ & 28.34 & 2.15 \\
\hline $\mathrm{SO}_{2}$ & 81.70 & 2.15 \\
\hline $\mathrm{NO}_{2}$ & 72.02 & 2.15 \\
\hline $\mathrm{PM} 2.5$ & 76.18 & 2.15 \\
\hline $\mathrm{PM} 10$ & 66.71 & 2.15 \\
\hline
\end{tabular}




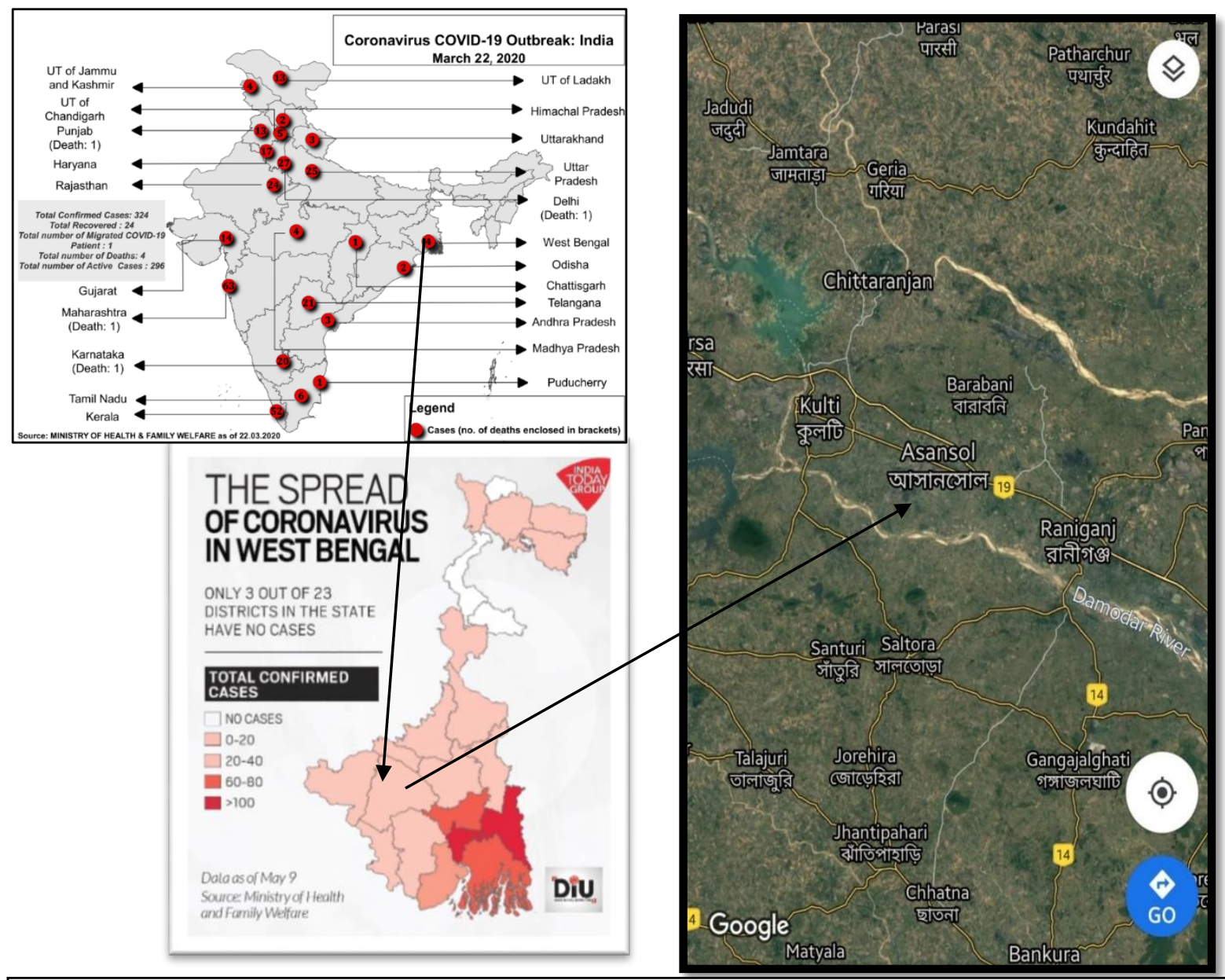

Fig. 1. Geographical distribution of COVID-19 cases all over India on $22^{\text {nd }}$ March, 2020 (Day of JANATA CURFEW) and location of the study area $\left(23.673^{\circ} \mathrm{N}, 86.952^{\circ} \mathrm{E}\right)$

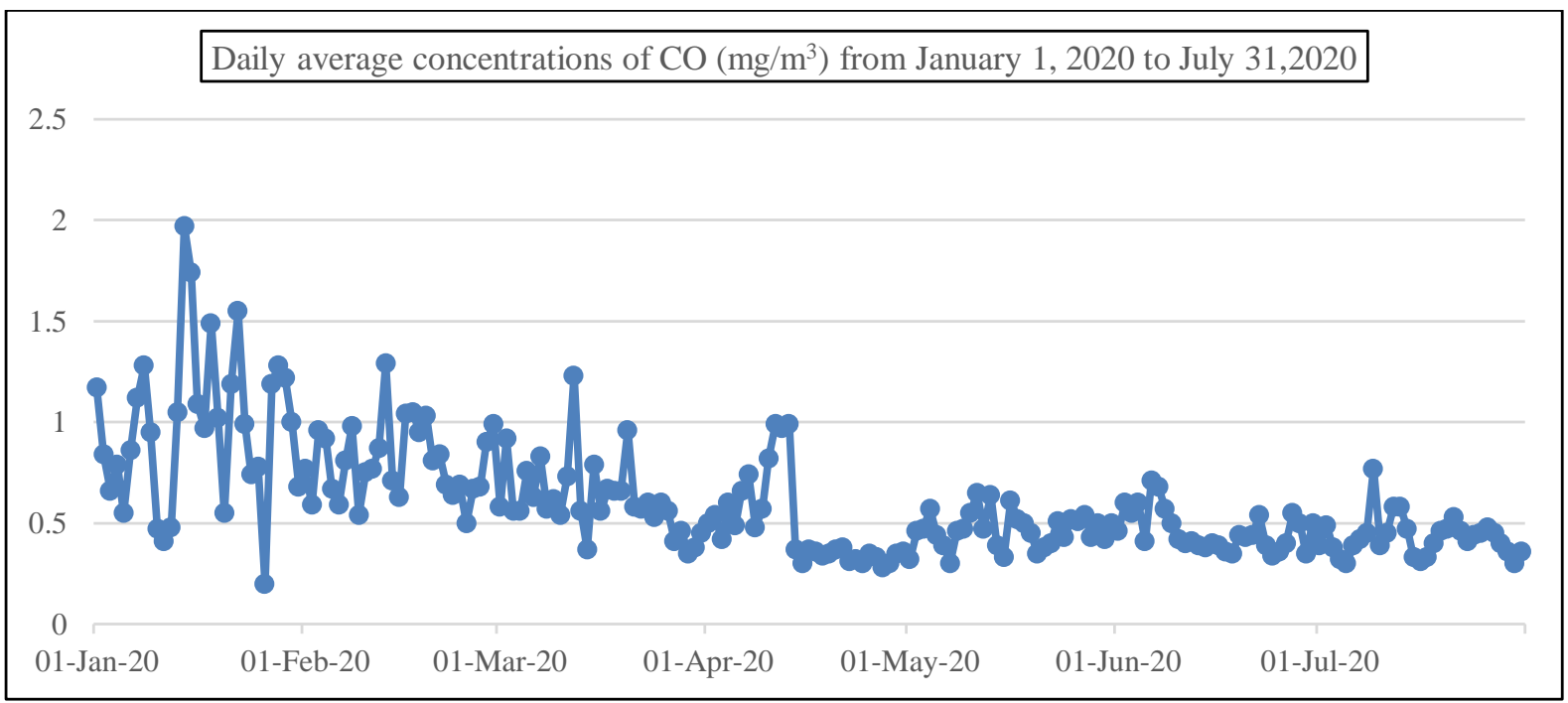

Fig. 2. The changing trend of atmospheric $\mathrm{CO}\left(\mathrm{mg} / \mathrm{m}^{3}\right)$ during study period 


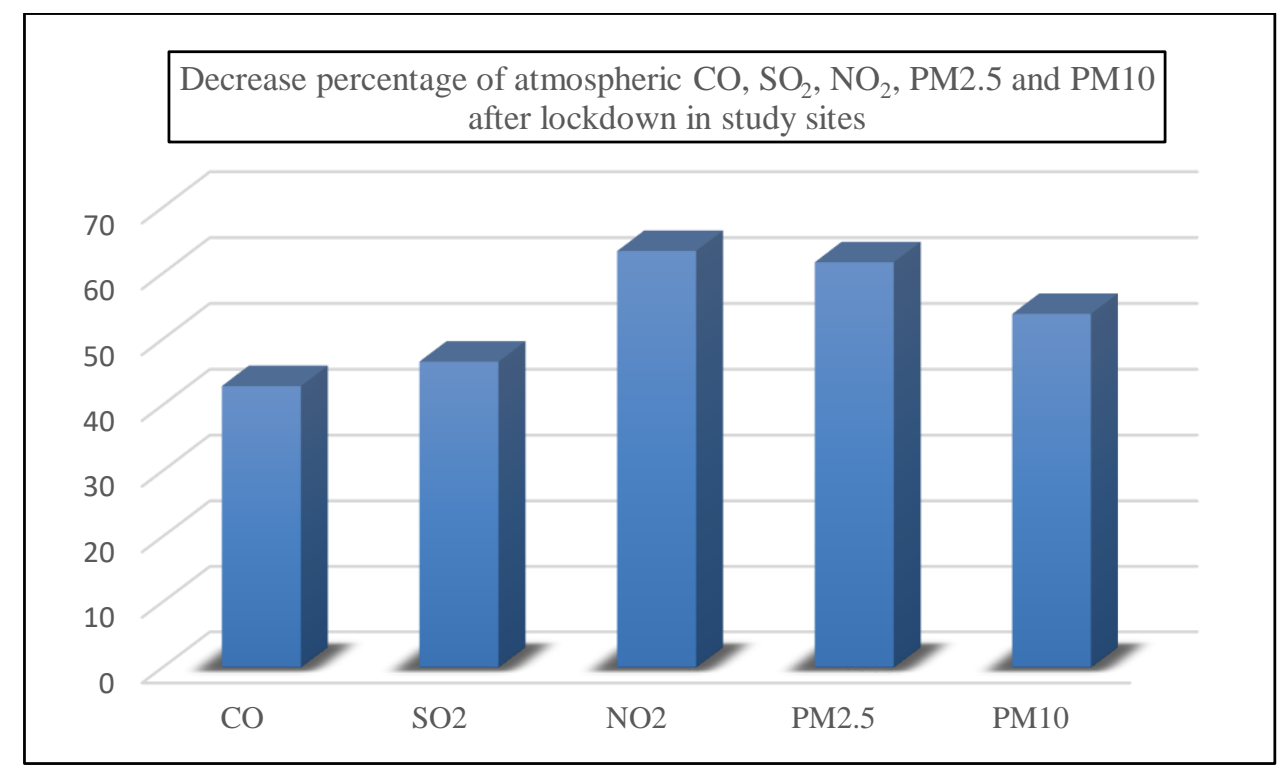

Fig. 3. The changing trend of atmospheric $\mathrm{SO}_{2}\left(\mu \mathrm{g} / \mathrm{m}^{3}\right), \mathrm{NO}_{2}\left(\mu \mathrm{g} / \mathrm{m}^{3}\right), \mathrm{PM} 2.5\left(\mu \mathrm{g} / \mathrm{m}^{3}\right)$ and PM10 $\left(\mu \mathrm{g} / \mathrm{m}^{3}\right) \mathrm{during}$ study period

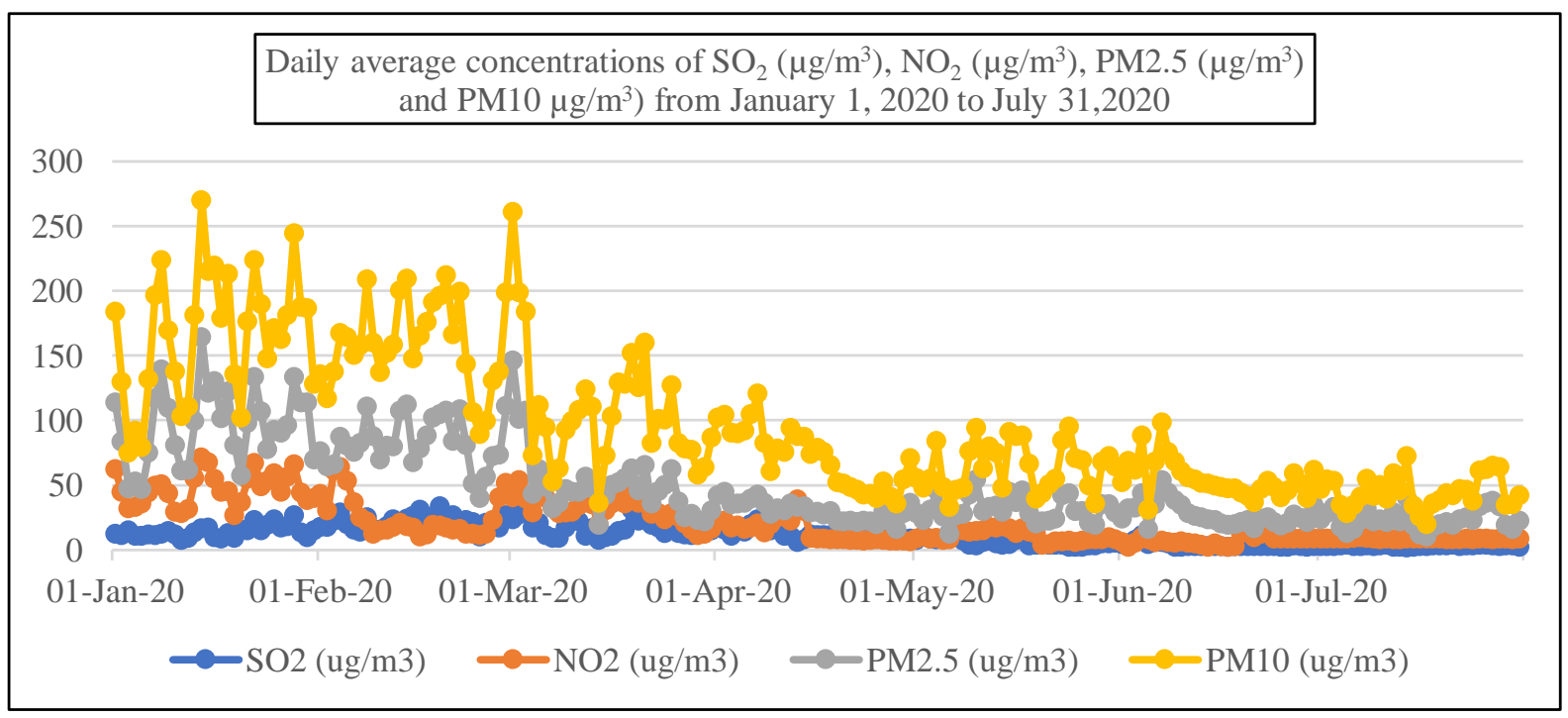

Fig. 4. Decrease percentage of atmospheric $\mathrm{CO}, \mathrm{SO}_{2}, \mathrm{NO}_{2}, \mathrm{PM} 2.5$ and PM10 during study period 


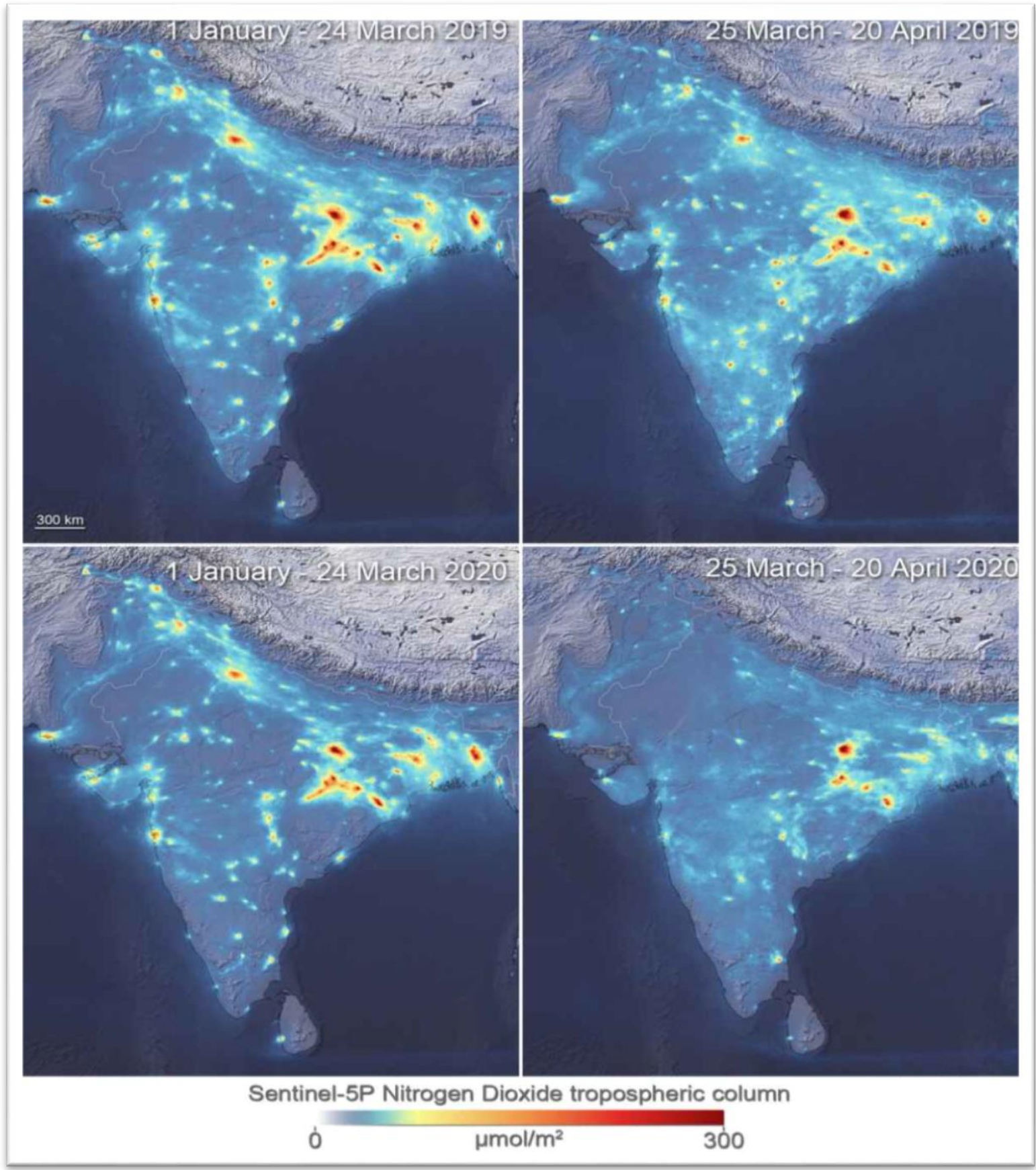

Fig. 5. $\mathrm{NO}_{2}$ emission over India before (January 1-April 20, 2019) and after (January 1-April 20, 2019) lockdown (Source: ESA, 2020a) 
I J R B A T, Issue (IX), Vol. II, May 2021: 257-268

OPEN $\bigcirc$ ACCES

e-ISSN $2347-517 X$

A Double-Blind Peer Reviewed \& Refereed Journal

Original Article

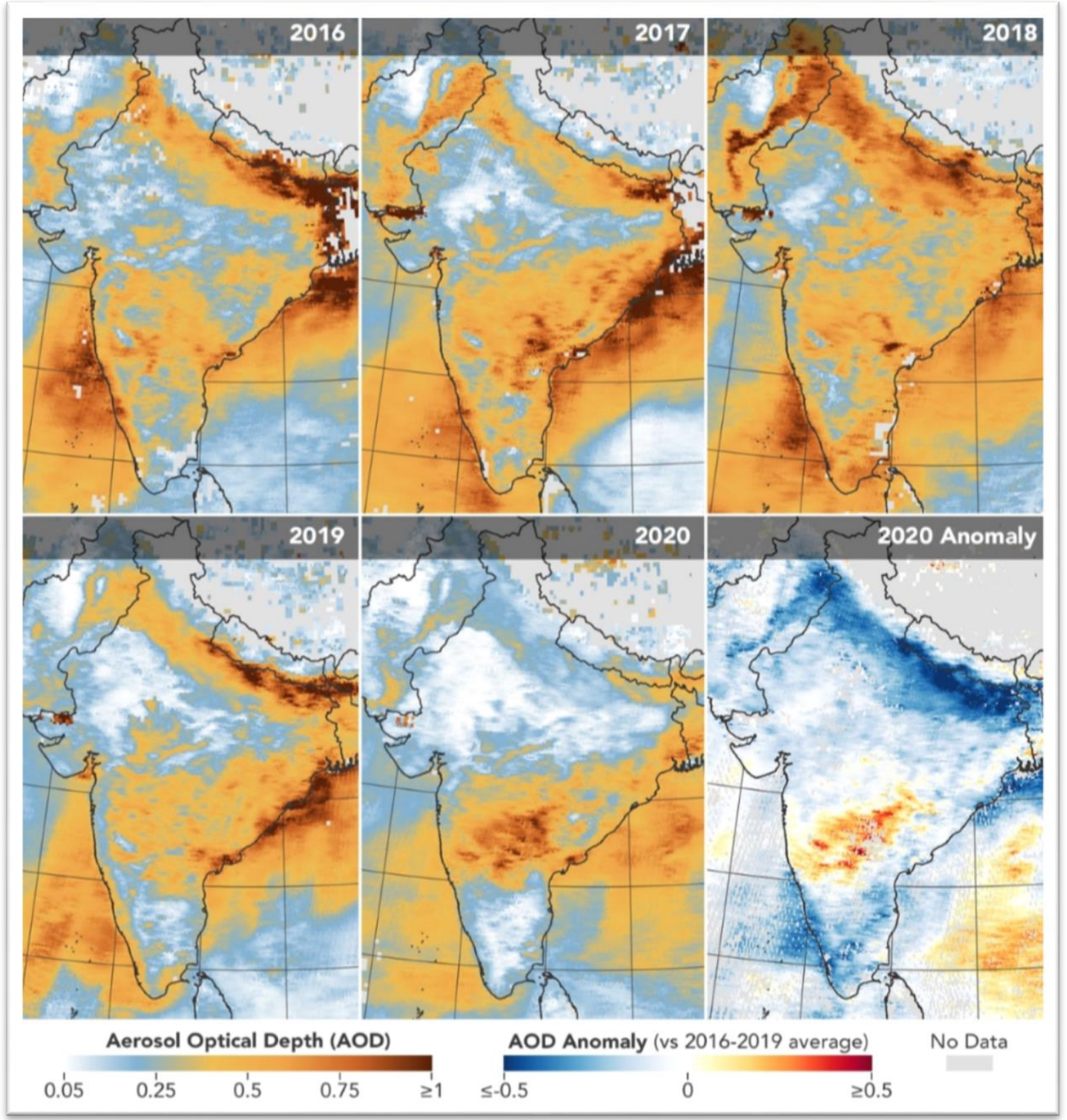

Fig. 6. The variation of aerosols optical depth (AOD) over Indian subcontinent from 2016 to 2020 and spatiotemporal anomaly of AOD in 2020 compared with 2016-2019(Source: NASA Air Quality Analysis, 2020) 